\title{
EVALUATION OF PALM FIBER COMPONENTS AN ALTERNATIVE BIOMASS WASTES FOR MEDIUM DENSITY FIBERBOARD MANUFACTURING
}

\author{
Abdel-Baset A. Adam ${ }^{1}$, Altaf H. Basta ${ }^{2, \AA}$,Houssni El-Saied ${ }^{2}$
}

\begin{abstract}
This work deals with assessing the date Palm component wastes as alternative lignocellulosic material for production of Medium density fiberboards, in order to establish economic and balance between production/consumer ratio at different provinces rather than Upper Egypt. Palm leafs and Palm frond was used as Medium density fiberboards precursors. Different urea formaldehyde levels (10-14\%/fiber) and pressing pressure (2.5-3.5 MPa) were applied in this evaluation. The acceptable interaction of Palm fibers component with urea formaldehyde was optimized by characterizing its differential scanning calorimetry and thermogravimetric analysis, in comparison with commercial used sugarcane bagasse fibers. The promising Medium density fiberboards Panel is obtained from Palm frond fibers and its mechanical and water resistance properties fulfill the ANSI standard for high grade Medium density fiberboards wood products, especially on applying urea formaldehyde level 12$14 \%$, and pressing pressure 3,5 $\mathrm{MPa}$. It is interesting to note that, applying higher pressing pressure together with $12 \%$ urea formaldehyde level provided Palm frond-based Medium density fiberboards with static bending properties, higher than commercial bagasse-based Medium density fiberboards. The insignificant effect of pressing pressure was noticed on water swelling property and free- $\mathrm{HCHO}$ of Medium density fiberboards panels. Where, both type of fibers have the same water swelling property (reached $\sim 10 \%)$, and free-HCHO $(\sim 27 \mathrm{mg} / 100 \mathrm{~g}$ board).
\end{abstract}

Keywords: Date Palm components, defibration process, fibers interaction, strength properties, thermal behaviour, urea formaldehyde, water resistance property.

\section{INTRODUCTION}

In Egypt agricultural wastes accumulate in huge quantities, it reaches about 35 MT/year. Part of this amount is used as animal fodder and to produce energy; as well as in production of paper and engineered wood products (particle and fiber boards). Still large amount of agro- wastes remains unused and it is burned in the open atmosphere causing environmental pollution. In laboratory scale some of wastes were used as filler for rubber composites, carbon materials, and hydrogels for water purification (El-Nashar et al. 2004, Ayrilmis and Winandy 2009, Basta et al. 2009, Basta et al. 2011, Sivakumar et al. 2012, Basta et al. 2013, Basta et al. 2014a and Basta et al. 2014b, Fathy et al. 2017). Sugar-can bagasse $(\mathrm{SCB})$ regards the main residue available and used as precursor for production of engineered wood products (particle-boards and Medium density fiberboards; MDF) and paper, in Upper Egypt. Our previous work was focused on examining the ability of controlling the steam digestion step; to improve the strength of SCB-based MDF produced (Adam et al. 2012).

Medium density fiberboards (MDF) and particleboards have replaced the natural wood, and plywood in

\footnotetext{
${ }^{1}$ Nag-Hamady Fiberboard Company, Quena, Upper Egypt.

${ }^{2}$ National Research Centre. Cellulose \& Paper Dept. El-Behoos Street, Cairo, Egypt.

•Corresponding author: altaf_basta2004@yahoo.com

Received: 22.01.2018 Accepted: 03.05.2018
} 
many furniture applications. MDF is superior to particleboards due to its properties including strength, homogeneity and machining performance (Akhtar et al. 2008, Halvarsson et al. 2008). They are also appropriate for interior and exterior construction, as well as in industrial applications. The preparation of particleboards and MDF in mill scale started from about four decades. The possibilities of utilizing the available agricultural wastes, (e.g., wheat, bagasse, rice straws, peanut husks, and hazelnut shells), using urea-formaldehyde, melamine-modified urea-formaldehyde, and soy-bean-pMDI adhesive systems in the production of engineered wood products has sparked attention with many authors (El-Saied et al. 1996, Faraji 1998, Lee et al. 2006, Ye et al. 2007, Akgul and Toslughu 2008, Copur et al. 2008, Hossein 2009, Ciannamea et al. 2010, Abolfazl and Ahmed 2011, Li et al. 2011, Basta et al. 2011, Basta et al. 2014a, Basta et al. 2014b and Basta et al. 2016, Younesi-Kordkheili and Pizzi 2018). Other trials in producing green artificial wood were carried out by using HCHO-free adhesive and changing the surface properties of natural lignocellulosic fibres by different grafting techniques (Roffael et al. 2011, Thakur et al. 2012a, Thakur et al. 2012b, Thakur et al. 2012c, Thakur et al. 2014), or by in-situ grafting of agro-fibres with the free styrene containing polyester (El-Saied et al. 2012). To improve the water resistance (WA and TS) of wood fibers-based MDF together with limitation of formaldehyde emission of promotion of the quality of the resins, wollastonite and its nano- particles were used in internal and surface treatments (Taghiyari and Nouri 2015, Taghiyari and Nouri 2016). However, surface treatment of MDF by Calcite (100\%), clay $(100 \%)$ or mixture of clay/calcite did not cause a significant difference on surface quality (Istek et al. 2012).

Date Palm is a multi-purpose tree; it regards a highly national heritage in many countries. It provides food, shelter, timber products. Because of these qualities, and its tolerance to harsh environmental desert conditions, areas under cultivation have increased tremendously in last decades (Mahmoudi et al. 2008). Egypt is the largest date producing country in the world. In 2012, it produced 1,47 million tones that make $19 \%$ of world dates production. Cultivation of date Palms in Egypt dates backs to thousands of years. Approximately seven million fruiting Palm trees are grown in Egypt in the Nile Valley, Sinai and similar areas.

Based on the availability of Palm date, as well as the environmental and economical impacts of sugar-cane bagasse from storage processes, the objective of this study is focused on evaluating the interaction of Palm component wastes (date Palm pruning mixed products, leaves \& frond), with commercial UF to be alternative substrate to manufacture of MDF. The success of this alternative material will be supported by comparing the MDF properties resulted from promising Palm component with that produced from bagasse fiber and the standard specifications (ANSI 208.2).

\section{MATERIALS AND METHODS}

\section{MDF Fibers and board preparation}

Date Palm rachises (DPR) were collected from date Palm trees grown up at Sinai. The used species is "EL BARMATODA". DPR were air dried in sun light for 48 hours, and then cut to $25 \times 25 \times 3 \mathrm{~mm}$ chips. These chips were softened by steam in a horizontal digester. The steam pressure was maintained at $\sim 0.8 \mathrm{MPa}$ for $6 \mathrm{~min}$. then defibrated through ANDRITZ refiner parallel experiments, sugarcane bagasse (SCB) samples were also subjected to the same condition of digestion and refining. The softening fibers were sunlight dried and mixed through laboratory blender with different levels of urea formaldehyde (UF) adhesive (based on oven dry basis) ratios as shown in Table 1. The UF was delivered from Speria Co., with free-formaldehyde (HCHO) $0,18 \%$. The ammonium sulfate ( $1 \%$ based on UF) was added as hardener, followed by $1 \%$ paraffin wax (based on dry fibers). The mats were formed and pre-pressed using $400 \mathrm{~mm} \times 400 \mathrm{~mm}$ box. Medium density fiberboard (MDF) boards with $12 \mathrm{~mm}$ thickness were made by hot pressing at different specific pressures condition as shown on Table 1 , at $165-170^{\circ} \mathrm{C}$ press temperature. For feasibility application such waste, the average weight of Palm fronds and Palm leaves in Palm waste are estimated and recorded in Table 2. 
Table 1. Experimental parameters.

\begin{tabular}{|c|c|c|c|c|}
\hline \multirow[b]{2}{*}{ sample code } & \multicolumn{3}{|c|}{ Additives } & \multirow{2}{*}{$\begin{array}{l}\text { sp. Press } \\
\left(\mathrm{kg} / \mathrm{cm}^{2}\right)\end{array}$} \\
\hline & $\begin{array}{c}\text { UF } \\
(\% / \text { Substrate })\end{array}$ & $\begin{array}{c}\text { Had } \\
(\% / \text { UF })\end{array}$ & $\begin{array}{c}\text { Wax } \\
(\% / \text { substrate })\end{array}$ & \\
\hline DPF & \multirow{6}{*}{ ( } & \multirow[t]{6}{*}{ (1) } & \multirow[t]{6}{*}{ (1) } & 25 \\
\hline $\mathrm{SCB}$ & & & & 25 \\
\hline DPF & & & & 30 \\
\hline SCB & & & & 30 \\
\hline DPF & & & & 35 \\
\hline $\mathrm{SCB}$ & & & & 35 \\
\hline DPF & \multirow{6}{*}{11} & \multirow{6}{*}{1} & \multirow{6}{*}{0,5} & 25 \\
\hline $\mathrm{SCB}$ & & & & 25 \\
\hline DPF & & & & 30 \\
\hline $\mathrm{SCB}$ & & & & 30 \\
\hline DPF & & & & 35 \\
\hline $\mathrm{SCB}$ & & & & 35 \\
\hline DPF & \multirow{6}{*}{12} & \multirow{6}{*}{1} & \multirow{6}{*}{0,5} & 25 \\
\hline $\mathrm{SCB}$ & & & & 25 \\
\hline DPF & & & & 30 \\
\hline $\mathrm{SCB}$ & & & & 30 \\
\hline DPF & & & & 35 \\
\hline $\mathrm{SCB}$ & & & & 35 \\
\hline DPF & \multirow{6}{*}{14} & \multirow{6}{*}{1} & \multirow{6}{*}{0,5} & 25 \\
\hline $\mathrm{SCB}$ & & & & 25 \\
\hline DPF & & & & 30 \\
\hline $\mathrm{SCB}$ & & & & 30 \\
\hline DPF & & & & 35 \\
\hline $\mathrm{SCB}$ & & & & 35 \\
\hline
\end{tabular}

DPF: DPF: date Palm fronds and SCB : Sugarcane bagasse

Table 2. UF resin specification.

\begin{tabular}{|c|c|c|c|c|}
\hline $\begin{array}{c}\text { Spec. Weight } \\
\left(\mathrm{kg} / \mathrm{m}^{3}\right)\end{array}$ & $\begin{array}{c}\text { Solid content } \\
(\%)\end{array}$ & $\begin{array}{c}\text { Viscosity } \\
(\mathrm{cp})\end{array}$ & $\begin{array}{c}\text { Gel time } \\
(\mathrm{s})\end{array}$ & $\begin{array}{c}\text { Free HCHO } \\
(\%)\end{array}$ \\
\hline 1275 & 60,55 & 378 & 68 & 0,18 \\
\hline
\end{tabular}

After open air-conditioning for $24 \mathrm{~h}$, these boards were cut according to standard sawing pattern into test specimens serving for the subsequent determination of basic mechanical and physical properties. Each result recorded in the following Figures is the average of five replicate measurements.

\section{Fiber analysis and MDF tests}

\section{Chemical analysis}

Parts of Date Palm rachises were subjected to mill, using sieve $250 \mu \mathrm{m}$ and $400 \mu \mathrm{m}$, followed by conditioning in polyethylene bags for 12 hours, and labeled to be ready for work. The chemical 
constituents (e.g., extractives, hollocellulose, a-cellulose, lignin and pentosans) were determined by standard methods (ASTM. 2003, Wise et al. 1946, TAPPI T429 1998, TAPPI T222 1978, Jayme and Sarten 1940).

\section{Thermogravimetric Analysis(TGA)}

The non-isothermal TGA of the selected representative adhesive systems, was carried out using Instrument SDT Q600 V20 Build 20 module (made at US), under nitrogen atmosphere at a heating rate of $10^{\circ} \mathrm{C} / \mathrm{min}$. The analysis was carried out on adhesive casting films $(\sim 7,032-9,40 \mathrm{mg})$, and their subjected to heat at temperature range from $\sim 30^{\circ} \mathrm{C}$ to $1000{ }^{\circ} \mathrm{C}$.

\section{*TG-curve analysis}

Kinetic studies, based on the weight loss data, were obtained by TG curve analysis. The activation energy against the appropriate order of degradation was evaluated by applying an analytical method proposed by Coats and Redfern (1964) and Basta and El-Saied 2008.

\section{Differential Scanning Calorimetry (DSC)}

Differential scanning calorimetry (DSC) is the thermoanalytical technique used to measure the thermal properties of the investigated adhesive systems, as phase transition and glass transition temperature. This analysis was carried out by employing DSC on the same previous Instrument SDT Q600 V20 Build 20 DSC module (made at US), on the dynamic run, also under nitrogen atmosphere at a heating rate of $10{ }^{\circ} \mathrm{C} / \mathrm{min}$.

\section{MDF Tests}

Different parameters of the MDF making involved different UF level (10-14\%) and pressing pressure $\left(25-35 \mathrm{kgf} / \mathrm{cm}^{2}\right)$ were carried out, as shown in Table 1 . The density of MDF was fixed by changing the amount of pressed fibers. The levels of UF were selected to provide MDF of E2 type with free-HCHO not exceed $27 \mathrm{mg} / 100 \mathrm{~g}$ board.

Three-point static bending (modulus of rupture; MOR), modulus of elasticity (MOE), and internal bond strength (IB) tests were performed in conformance with ASTM D1037-94 and ANSI A208.21994, for MDF panel's requirements for interior uses, using a IMAL IB500 testing machine.

For evaluating the low toxicity of the resulted composites, the perforator method (EN 120, 1992) for determination of free-HCHO in composites was carried out.

\section{Statistical Analysis}

The data of the mechanical and physical properties of MDF samples manufactured from bagasse, frond, and mixed frond fibers were subjected to statistical data handling through the TWO WAY (ANOVA) variance analysis by using IBM SPSSV20 software in order to evaluate the significance of the board properties. The statistical analyses were carried out separately for both glue additions and pressing pressure.

\section{RESULTS AND DISCUSSION}

\section{Characterization of fibers}

The chemical analysis and average weight of Palm components were studied to examine their chemical constituents in comparison with sugar-cane bagasse, which is a commercial substrate used in local MDF mill; as well as, to estimate it's available as alternative biomass instead of bagasse. Thermal analyses (DSC and non-isothermal TGA) were carried out to examine the interaction of UF 
adhesive with the foregoing agro-fibers. The importance of chemical constituents depends on the fact that, the relatively higher cellulose content may imparts the fiber strength; while the extractives will represent serious influence on the steam digestion process, and consequently MDF produced. Because, steam digestion process regards important step operation in manufacturing process, which facilitates the individualization of the fibers, and enhanced MDF formation. Moreover, the available amount of this waste for MDF production and the positive interaction between fibers and UF during resinification and curing processes are also very required for production acceptable MDF.

The results obtained are illustrated in Tables 3-6 and Figure 1 and Figure 2. Table 3 shows that, leafs of date Palm included higher extractives and lignin content together with lower cellulose and hemicellulose contents compared with Palm frond component and SCB. The higher cellulose content together with hemicellulose in case of Palm frond will play profound effect on fiber strength and self resinification of fiber during exposing to high temperature and pressure. This observation persuades us to recommend this waste in further work as precursor for production of MDF. Moreover to exclude the serious problem effect of extractives included the leaf on the machines of steam and fibrilization processes. Also, this view is emphasized from the relatively higher average weight percentages of Palm fronds $(\sim 57 \%)$ than Palm leaves $(43 \%)$, Table 4.

Table 3. Chemical analysis of date Palm frond and leaves.

\begin{tabular}{|l|c|c|c|}
\hline Test/Material & $\begin{array}{c}\text { DPR } \\
\text { Frond }\end{array}$ & $\begin{array}{c}\text { DPL } \\
\text { Leaves }\end{array}$ & $\begin{array}{c}\text { SCB } \\
\text { Bagasse }\end{array}$ \\
\hline H.Cell \% & 69,96 & 42,44 & 74,14 \\
\hline a- Cell \% & 38,99 & 22,66 & 42,58 \\
\hline Hemi \% & 30,97 & 18,78 & 31,56 \\
\hline lignin \% & 18,55 & 25,65 & 18,22 \\
\hline Pentosan \% & 24,79 & 16,65 & 29,22 \\
\hline Water Ex. \% & 14,16 & 24,24 & 3,97 \\
\hline Solvent Ex. \% & 1,6 & 4,95 & 1,82 \\
\hline Total Ex. \% & 15,76 & 29,19 & 5,79 \\
\hline NaOH \% & 29,26 & 57,79 & 34,5 \\
\hline Ash \% & 5,82 & 5,36 & 2,85 \\
\hline
\end{tabular}

H. Cell $\%=$ holocellulose $\%$, a-cell $\%=$ a-cellulose $\%$, Hemi $\%=$ Hemicellulose $\%$, Water Ex $\%$ \& Solvent Ex $\%=$ water \& solvent extractives $\%$ respectively, Total Ex. $\%=$ total Extractives $\%, \mathrm{NaOH} \%=$ solubility in $1 \% \mathrm{NaOH}, \mathrm{C} . \mathrm{W} \%=\mathrm{Cold}$ water solubility \%.N.B. Hemicellulose content $\%$ \& total Extractives can be calculated as follow Hemicellulose $\%=($ H.Cell $\%)-(\mathrm{a}-\mathrm{cell} \%)$ and Total Extractives \% = Water Ex \% + Solvent.

Table 4. Average weight of fresh cut date Palm components.

\begin{tabular}{|lccc|}
\hline Test/Material & $\begin{array}{c}\text { Avg. } \\
\text { Weight }\end{array}$ & $\begin{array}{c}\text { DPR } \\
\text { Frond }\end{array}$ & $\begin{array}{c}\text { DPL } \\
\text { Leaves }\end{array}$ \\
\hline Frond with leaves & 2,35 & 1,45 & 0,9 \\
\hline Moisture content & 50,00 & 54,00 & $45 \%$ \\
\hline Dry weigh & 1,18 & 0,67 & 0,50 \\
\hline$\%$ & & 56,8 & 43,2 \\
\hline
\end{tabular}




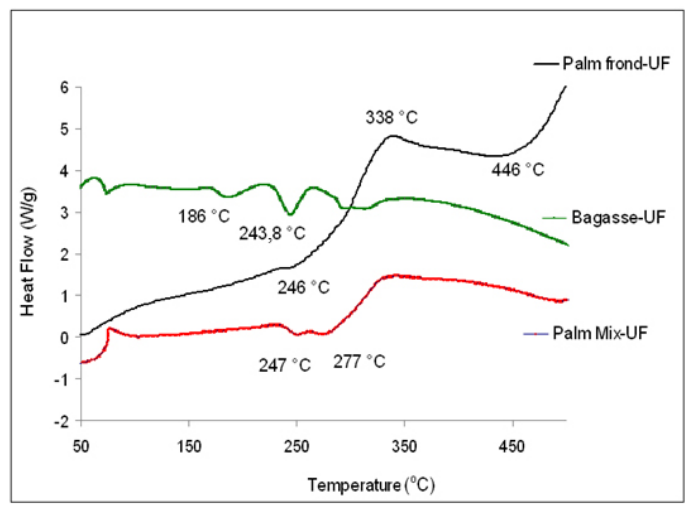

Figure 1. DSC of Palm frond fibers with UF in comparison with Bagasse fibers-UF.
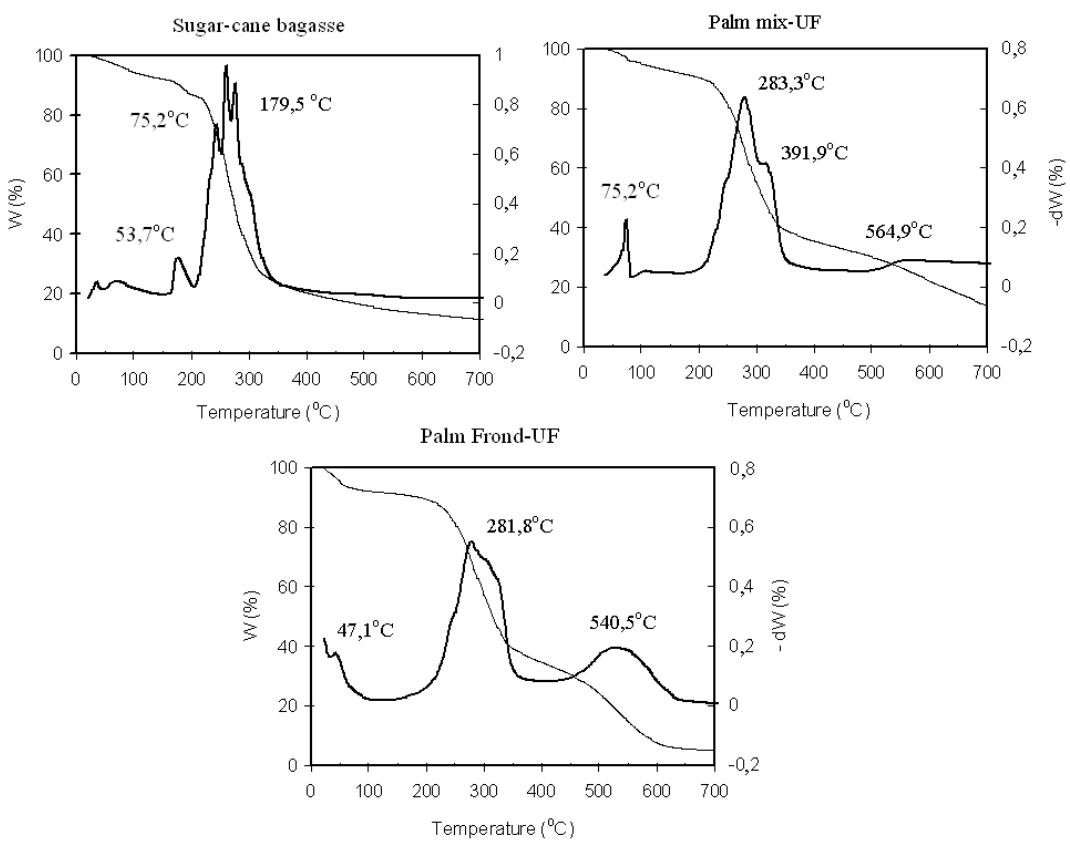

Figure 2. Thermo-gravimetric weight loss and derivative curves of Palm frond fibers with UF in comparison with Bagasse fibers-UF.

For application in industrial scale and to reduce the effect of extractives, further study was carried out on possibility of using frond and leafs in blend, as a precursor fibrous of MDF production. To recommend the possible using blend-based fibers, its interaction with UF should be studied, in comparison with both Palm frond and bagasse fibers. In this respect DSC and TGA of Fibers-UF samples were studied.

For thermal analysis of resinated fibers, the differential scanning Calorimetry (DSC) and the non-isothermal thermogravimetric (TGA) analyses are shown in Figure 1 and Figure 2; while their calculated parameters are recorded in Tables 5 and Table 6. 
Table 5. DSC analysis of the main Endothermic event of Bagasse- and Palm components-UF samples.

\begin{tabular}{|c|c|c|c|c|c|c|}
\hline \multirow{2}{*}{ Sample } & \multicolumn{3}{|c|}{ First step of curing reaction } & \multicolumn{3}{c|}{ Second step of curing reaction } \\
\cline { 2 - 7 } & $\mathrm{T}_{\mathrm{o}}\left({ }^{\circ} \mathrm{C}\right)$ & $\mathrm{T}_{\mathrm{p}}\left({ }^{\circ} \mathrm{C}\right)$ & $\mathrm{rT}\left({ }^{\circ} \mathrm{C}\right)$ & $\mathrm{T}_{0}\left({ }^{\circ} \mathrm{C}\right)$ & $\mathrm{T}_{\mathrm{p}}\left({ }^{\circ} \mathrm{C}\right)$ & $\mathrm{rT}\left({ }^{\circ} \mathrm{C}\right)$ \\
\hline \multirow{2}{*}{ Bagasse -UF } & 191,8 & 226,9 & 35,1 & 322,5 & 359,2 & 36,7 \\
& 246,9 & 272,0 & 25,1 & & & \\
\hline \multirow{2}{*}{ Palm mix-UF } & 238,31 & 248,99 & 10,68 & 506,62 & 563,22 & 56,60 \\
\hline Palm Frond-UF & 288,84 & 340,01 & 51,17 & & & \\
\hline
\end{tabular}

Table 6. TGA kinetic parameters of Bagasse- and Palm components-UF samples.

\begin{tabular}{|l|c|c|c|c|c|c|c|c|}
\hline $\begin{array}{l}\text { Sample code } \\
\text { in chart }\end{array}$ & stage & $\begin{array}{c}\text { Temp. range } \\
{ }^{\circ} \mathrm{C}\end{array}$ & $\begin{array}{c}\text { DTG peak } \\
\text { Temp., }{ }^{\circ} \mathrm{C}\end{array}$ & "n” & $\mathrm{R}^{2}$ & $\mathrm{SE}$ & $\begin{array}{c}\mathrm{E}_{\mathrm{a}} \\
\mathrm{kJ} / \mathrm{mole}\end{array}$ & $\begin{array}{c}\text { Wt. remain } \\
\%\end{array}$ \\
\hline \multirow{3}{*}{ Bagasse-UF } & $1^{\text {st }}$ & r.t.-100,4 & - & - & - & - & - & 94,46 \\
& $2^{\text {nd }}$ & $157,2-211,6$ & 179,5 & 1,0 & 0,985 & 0,168 & 173,01 & 86,24 \\
& 3 rd & $211,6-390,5$ & 261,5 & 2,0 & 0,980 & 0,230 & 127,25 & 20,82 \\
\hline \multirow{4}{*}{ Palm Mix-UF } & $1^{\text {st }}$ & r.t- 106,5 & 75,2 & - & - & - & - & 94,57 \\
& $2^{\text {nd }}$ & $164,8-302,7$ & 283,3 & 1,0 & 0,988 & 0,1087 & 84,82 & 53,33 \\
& $3^{\text {rd }}$ & $302,7-328,4$ & 391,9 & 1,5 & 0,985 & 0,146 & 117,90 & 40,22 \\
& 4 th & $461,3-700,0$ & 564,9 & 1,5 & 0,968 & 0,156 & 94,30 & 6,86 \\
\hline \multirow{3}{*}{ Palm Frond-UF } & $1^{\text {st }}$ & r.t- 104,33 & 33,7 & - & - & - & - & 91,97 \\
& $2^{\text {nd }}$ & $150,4-398,5$ & 281,8 & 1,0 & 0,989 & 0,125 & 64,18 & 34,74 \\
& $3^{\text {rd }}$ & $398,5-651,9$ & 540,5 & 0,5 & 0,982 & 0,124 & 124,06 & 5,53 \\
\hline
\end{tabular}

With regard to DSC, Figure 1 shows that, the resinated fibers of Palm leafs and frond blend with UF exhibits three peak temperatures like bagasse- UF. While, its DSC profiles exhibit an endothermic peaks at relatively higher temperature $\left(248,99^{\circ} \mathrm{C}, 340,01^{\circ} \mathrm{C}\right.$ and $\left.563,22^{\circ} \mathrm{C}\right)$, than bagasse-UF $\left(226,9^{\circ} \mathrm{C}\right.$, $272,0^{\circ} \mathrm{C}$ and $359,2^{\circ} \mathrm{C}$ ). The rT value of each peak, which calculated from the peak temperature and onset temperature $\left(T_{p}-T_{\mathrm{p}}\right)$, is a measure of curing rate and recorded in Table 5. Table 5 shows that the thermal curing of Palm fibers- UF behaves at lower temperatures than that of the commercial bagasse-UF. The rT value of $1^{\text {st }}$ peak is about $10,68{ }^{\circ} \mathrm{C}$ for the whole Palm fibers; while in case of bagasse fiber is $35,1^{\circ} \mathrm{C}$. The relatively lower value of $\mathrm{rT}$ in the case of blending from Palm components (Palm mix), indicates a higher rate of curing. While, in the case of bagasse-UF, curing is started at lower temperature and gives a higher value of rT, which means lower rate of curing. This trend is probably accompanied by shorting the time of penetrating the UF adhesive through whole Palm fibers, and weakness the adhesion between the fibers, due to fast the condensation of UF adhesive on fiber surface. This unaccepted trend is reduced on using Palm frond, whereas the difference values of onset temperature and peak temperature (rT) are also increased than those observed in bagasse-UF. Where, rT for the main peaks are $47,15^{\circ} \mathrm{C}$ and $76,29^{\circ} \mathrm{C}$; while for bagasse are 35,1 and $36,7^{\circ} \mathrm{C}$.

With regard to non-isothermal thermogravimetric analysis, Figure 2 illustrates the TGA and DTG curves of the blend of Palm components (Palm mix) and Palm frond resinated fibers with UF, in comparison with bagasse fibers-UF. Table 6 summarizes their kinetics parameters. Figure 2 shows that, there are three decomposition steps for bagasse-UF and Palm frond-UF resinated fibers. The first one at temperature lower than $100{ }^{\circ} \mathrm{C}$, indicates the evolution of adsorbed water, in addition to second 
and third steps, in the ranges from $150-399{ }^{\circ} \mathrm{C}$ and $211-652{ }^{\circ} \mathrm{C}$ corresponding to volatilization and carbonization (degradation of selected adhesive systems. The ranges of degradation stages of Palm frond-UF $\left(150,4-398,5^{\circ} \mathrm{C}\right.$ and $\left.398,5-651,9^{\circ} \mathrm{C}\right)$ are greater than bagasse-UF $\left(157,2-211,6^{\circ} \mathrm{C}\right.$ and $211,6-$ $\left.390,5^{\circ} \mathrm{C}\right)$. Moreover, the peak temperature of these degradation stages in case of Palm frond $\left(281,8^{\circ} \mathrm{C}\right.$ and $\left.540,5^{\circ} \mathrm{C}\right)$ is higher than bagasse $\left(179,5^{\circ} \mathrm{C}\right.$ and $\left.261,5^{\circ} \mathrm{C}\right)$. This indicates the slowness degradation of resinated Palm frond than bagasse (higher thermal stability). This observation is in agreement with that found by DSC which supports the curing of UF on Palm frond fibers is occurred at longer time.

With regard to the blend of Palm components (leafs + frond), it is observed that the volatilization is occurred in 2 stages with DTG peaks $283,3{ }^{\circ} \mathrm{C}$ and $391,9{ }^{\circ} \mathrm{C}$; while the carbonization stage with DTG peak at $564,9^{\circ} \mathrm{C}$. This is probably related to the relatively higher extractives included Palm leafs, which resist to some extent the role of steam and digestion process, and consequently it may affects the individualization of the fibers and interaction with UF. This extractive leads to increase the activation energy required for volatilization stage $(\Sigma \mathrm{Ea}=202,7 \mathrm{~kJ} / \mathrm{mole})$ than the case of Palm frond $(64,2 \mathrm{~kJ} /$ mole and bagasse $173,01 \mathrm{~kJ} / \mathrm{mole}$, respectively).

Based on the foregoing results of chemical constituents and thermal analysis, the Palm frond was candidate as substrate for MDF production. Till it possible to use as alternative to commercial bagasse, the properties of MDF made from both fibers are compared.

\section{Properties of MDF}

The influence of preparation parameters, e.g., UF level and pressing pressure on the performance of MDF produced from Palm frond and SCB fibers are illustrated graphically in Figures 3-9.
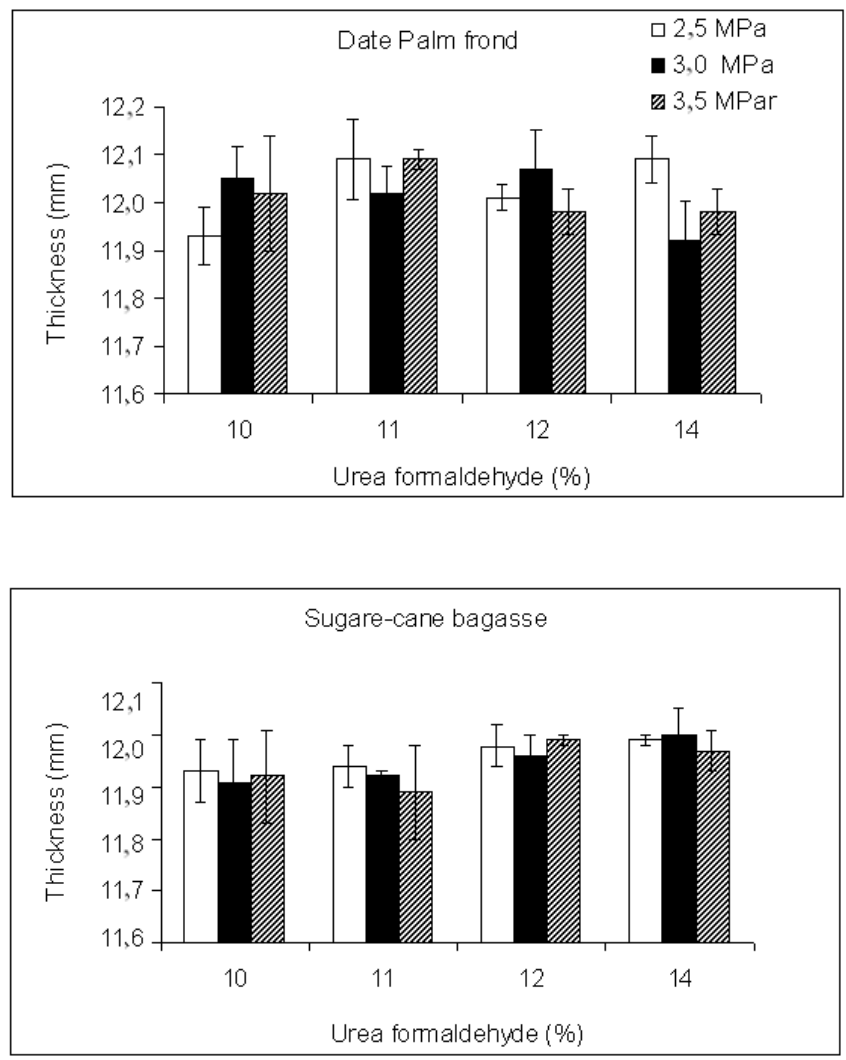

Figure 3. Variation of Thickness of MDF of Palm frond and Bagasse fibers versus UF \%. 

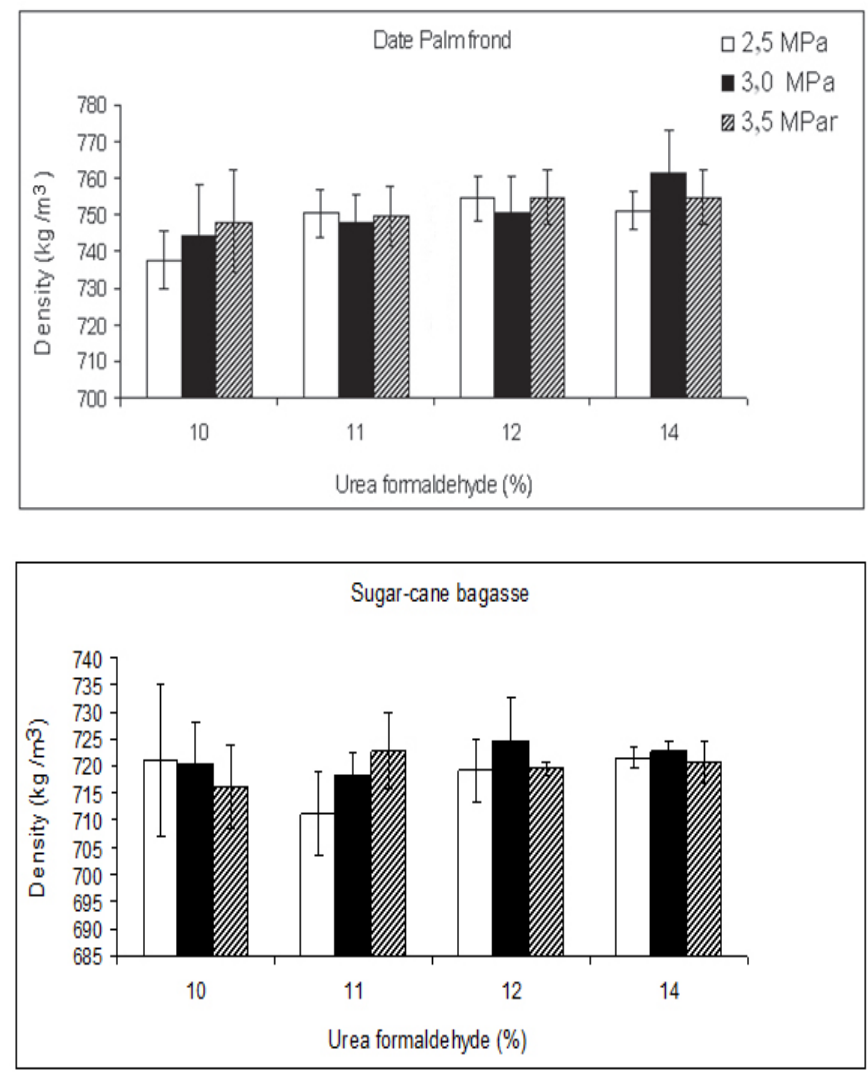

Figure 4. Variation of Gross density of MDF from Palm frond and Bagasse fibers versus UF \% and specific pressure.

Figure 3 and Figure 4 show that, changing the UF \% together with specific pressure provided board from Palm frond and bagasse with thickness $\sim 12 \mathrm{~mm}$; while for board density in case of Palm frond fibers is around $750 \mathrm{~kg} / \mathrm{m}^{3}$. This value is higher than that made from bagasse $\left(\sim 720 \mathrm{~kg} / \mathrm{m}^{3}\right)$; Figure 4 . Higher board density is observed in case of board made from Palm frond fibers at relatively higher UF\% (14\%) and applied specific pressure (3,5 MPa) (it reached $762 \mathrm{~kg} / \mathrm{m}^{3}$ ). Static bending (MOR and MOE), and IB are greatly affected by changing both UF\% and specific pressure (Figures 5-7). At relatively lower UF\%, the specific pressure has a profound effect (improvement) on strength properties of MDF than higher ones. Where, for boards made from Palm frond fibers, at $10 \% \mathrm{UF}$, changing the specific pressure accompanied by increasing in MOR, from $17 \mathrm{MPa}$ to $22 \mathrm{MPa}, \mathrm{MOE}$ from 1811,6 MPa to $2368,8 \mathrm{MPa}$, and IB from $0,46 \mathrm{MPa}$ to $0,57 \mathrm{MPa}$. While, on applying $14 \%$, the changes in MOR, MOE and IB with increasing the specific pressure from 2,5 MPa to 3,5 MPa are from 30 to $34 \mathrm{MPa}$, from 3153 to $3579 \mathrm{MPa}$, and from 1,0 to $1,15 \mathrm{MPa}$, respectively. A similar improvement is observed in case of SCB-based MDF. It is interesting to note that, both Palm frond and bagasse fibers at $12-14 \%$ UF, and different specific pressure provided MDF boards fulfill the requirement of high grade MDF reported according to ANSI standard. In other words, the increasing in UF level was more significant on producing high quality MDF than specific pressure. 

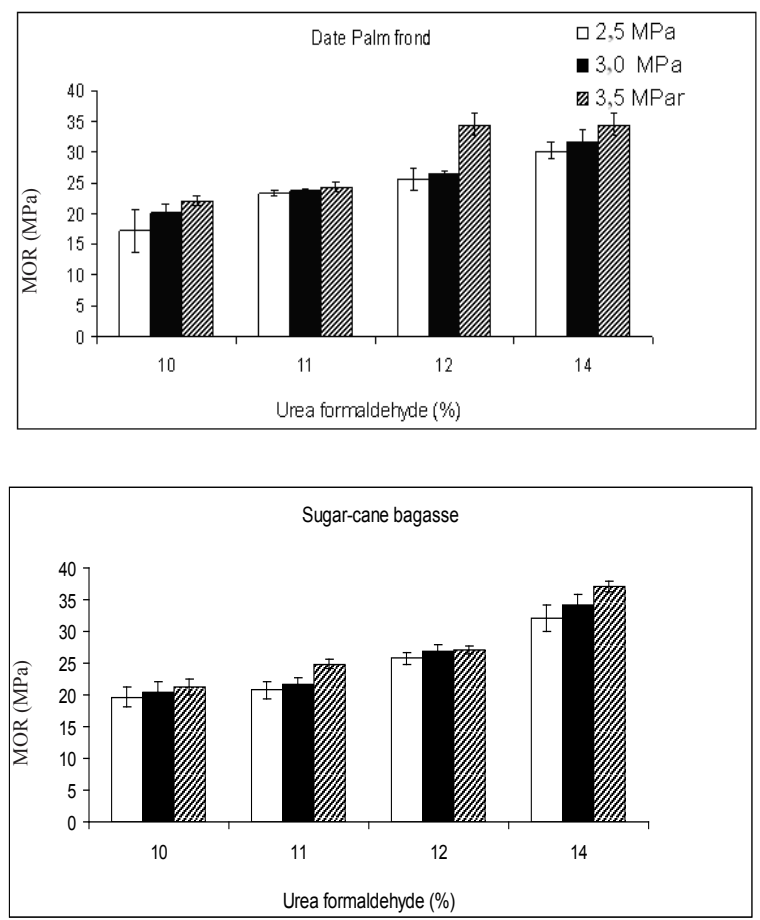

Figure 5. Variation of MOR of MDF from Palm frond and Bagasse fibers versus UF $\%$ and specific pressure.
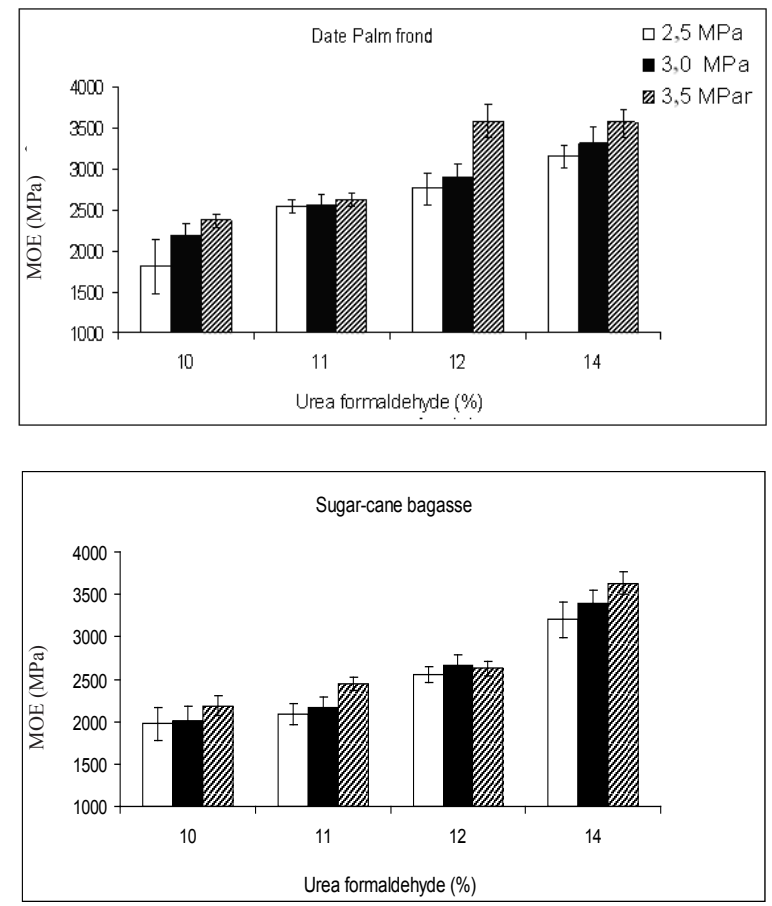

Figure 6. Variation of MOE of MDF from Palm frond and Bagasse fibers versus UF \%. and specific pressure. 

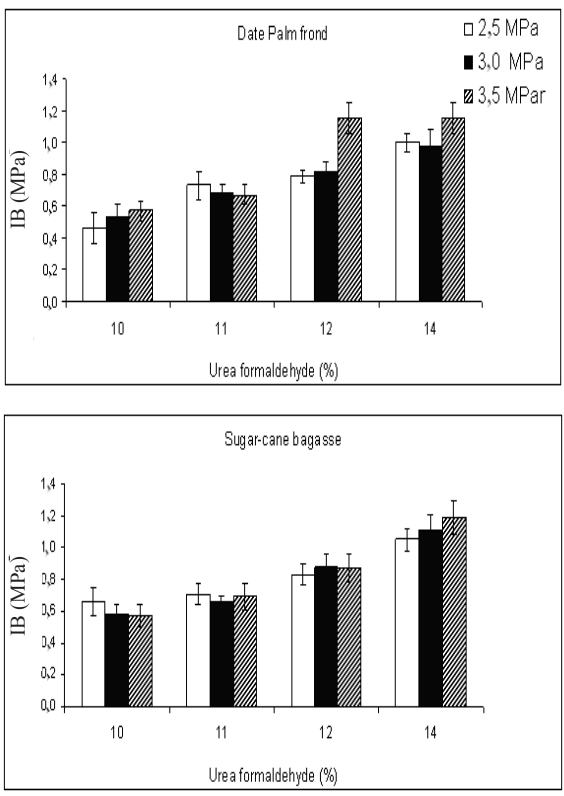

Figure 7. Variation of IB of MDF from Palm frond and Bagasse fibers versus UF \% and specific pressure.

Results for the thickness swelling (SW) of the various MDF produced under the foregoing parameters are illustrated in Figure 8. It is clear that, the SW property of MDF decreased (improved) considerably as UF $\%$ increased from $10 \%$ to $14 \%$. Greater reducing in this property is observed at relatively lower specific pressure $(2,5 \mathrm{MPa})$, where SW decreased from $17 \%$ to $11 \%$ and from $15 \%$ to $10 \%$, in case of Palm frond- and Bagasse-based MDF, respectively. Increasing the applied specific pressure to 3,5 $\mathrm{MPa}$, together with $\mathrm{UF} \%$ up to $14 \%$ provides SW value $\sim 10 \%$, in both types of fibersbased MDF. However, the changing in pressing pressure is not significant on free-HCHO of MDF produced, where its value between 25,88 to $27,95 \mathrm{mg} / 100 \mathrm{~g}$ board.
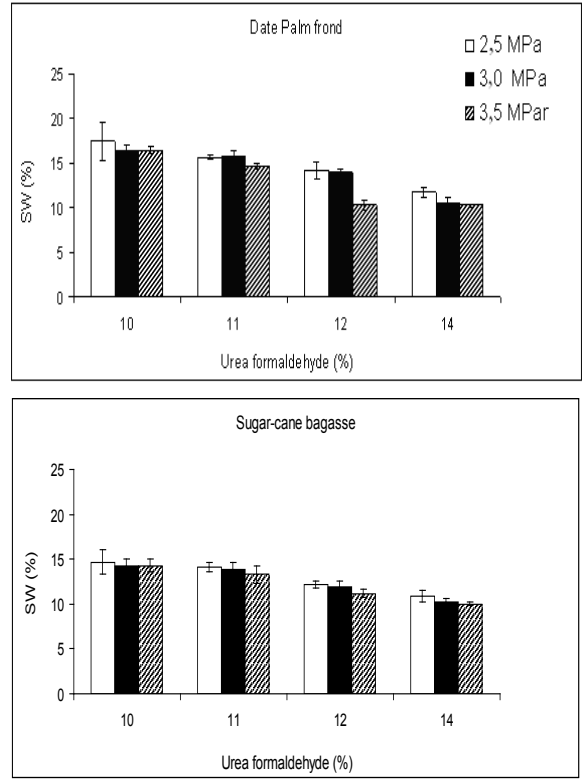

Figure 8. Variation of water swelling of MDF from Palm frond and Bagasse fibers versus UF \% and specific pressure. 


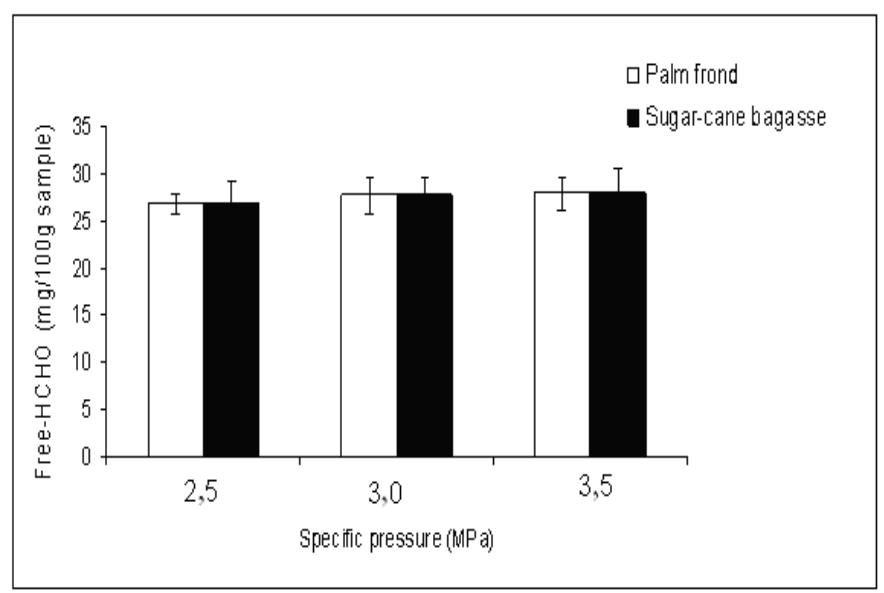

Figure 9. Free-HCHO of MDF Palm frond and Bagasse fibers versus specific pressure.

The explanation of the foregoing data may be ascribed to enhance the bond formation with increasing adhesive level and specific pressure, as well as due to the substrate constituents. Higher cellulose and hemicelluloses as well as lower extractives contents of sugar cane bagasse provide fibers easily adhered together during MDF formation, than Palm frond fibers. Higher adhesive level and pressing pressure enhancing the affinity of Palm frond fibers to response for adhering together during hot pressing.

For specifying the application of MDF produced from both fibers, as reported and based on ANSI and EN Standards, the MDFs produced from Palm frond and bagasse fibers, especially with $12-14 \%$ UF and Specific pressure 3,0-3,5 MPa have higher values than the requirements for general purposes. These boards fulfill the requirements for strength and thickness swelling properties reported in ANSI Standard. According to TS and HCHO these boards are possible for load-bearing applications and specified as E2 type boards.

The ANOVA analysis was carried out for mechanical properties and physical properties as shown, for example, in Tables 7-8. These data show a significant differences between the static bending of MDF samples made from bagasse fiber, fronds fiber, and mixed frond and frond leaves, at different addition of UF adhesive. The levels of glue addition is slightly significant on properties of MDF boards made from mixed and frond fiber than those made from bagasse, with higher specific pressure of hot press.

For economical potential of using Palm frond fibers, it will preserve the additional cost required for storage of bagasse and transportation. Moreover, this waste is available in many provinces, and persuades to construct wood Mills, without concerning on the Mills of upper-Egypt.

\section{CONCLUSIONS}

Due to the availability of date Palm at different provinces, and for trial to minimize the economical and environmental impacts from storage of sugar-cane bagasse (SCB), as a substrate for production MDF, in this article we evaluated the Palm fibers components on the quality of produced MDF. The performance of Palm-based MDF was also evaluated, in comparison with traditional prepared SCBbased MDF. The results of chemical constituents of date Palm components (leafs and fronds), their 
average weights, as well as Fibers-UF interactions (via DSC and TGA studies) lead us to recommend the use of date Palm frond (DPF) in production of MDF. DPF-based MDF especially with $12-14 \%$ UF and specific pressure 3,5 $\mathrm{MPa}$ have acceptable properties as compared to those produced from sugar-cane bagasse. It is static bending (MOR and MOE), internal bond strength (IB) fulfilled the high requirements in mechanical and thickness swelling properties of ANSI and EN standards. Where, their values were $34,4 \mathrm{MPa}, 3579,2 \mathrm{MPa} 1,15 \mathrm{MPa}$ and $10,2 \%$, respectively.

\section{ACKNOWLEDGMENTS}

The authors are grateful to Nag-Hamady Co. for Fiberboard-Quena, Egypt for providing the raw materials and equipment for the experimental study.

\section{REFERENCES}

Abolfazl, S.; Ahmed, J.L. 2011. The performance of corn and cotton stalks for medium density fiberboard production. Bioresources 6: 147-57.

Adam, A.A.; Basta, A.H.; El-Saied, H. 2012. Performance of bagasse-based medium density fiberboard produced from different steam digestion retention times. Forest Products Journal 62(5): 400-405.

Akgul, M.; Toslughu, A. 2008. Utilizing peanut husk in the manufacture of medium density fiberboards. Bioresource Technology 99: 5590- 94.

Akhtar, M.; Kenealy, W.R.; Horn, E.G.; Swaney, R.E.; Winandy, J.E. 2008. Method of making medium density fiberboard. US Patent No: US 2008/0264588 A1.

American National Standardization Institute. ANSI. 1994. Medium Density Fiberboard. ANSI 208.2. 1994

American Society and Materials. ASTM. 1994. Standard test for evaluation the properties of wood-based and particle panel materials. Philadeplia, PA. ASTM D1037-94.

American Society and Materials. ASTM. 2003. Determination of ethanol extractives in bagasse ASTM E1690. 2003. In: Annual book of ASTM Standards, Philadelphia, PA: 11.05.

Ayrilmis, N.; Winandy, J.E. 2009. Effect of post heat treatment on surface characteristics and adhesive bonding performance of MDF. Materials and Manufacturing Processes 24: 594-599.

Basta, A.H.; El-Saied, H. 2008. New approach for utilization of cellulose derivatives metal complexes in preparation of durable and permanent colored papers. Carbohydrate Polymers 74 (2): 301-308.

Basta, A.H.; Fierro, V.; El-Saied, H.; Celzard, A. 2011. Effect of Deashing Rice Straws on their derived Activated Carbons produced by Phosphoric Acid Activation. Biomass and Bioenergy 35: 1954-1959.

Basta, A.H.; El- Saied, H.; Winandy, J.E.; Sabo, R. 2011. Preformed amide-containing biopolymer for improving the environmental performance of synthesized urea-formaldehyde in Agro- 
fibre Composites. Journal of Polymers and the Environment 19 (2): 405-412.

Basta, A.H.; El-Saied, H.; El-Hadi, O.; El-Dewiny, C. 2013. Evaluation of rice straw-based hydrogels for purification of wastewater. Polymer Plastic Technology and Engineering 52 (11): 10741080 .

Basta, A.H.; El-Saied, H.; Lotfy, V.F. 2013. Performance of rice straw-based composites using environmentally friendly polyalcoholic polymers-based adhesive system. Pigment and Resin Technology 42 (1) 24-33.

Basta, A.H.; El-Saied, H.; Lofty, V.F. 2014a. Performance assessment of deashed and dewaxed rice straw on improving the quality of RS-based composites. RSC Advances 4 (42) : 21794-21801.

Basta, A.H; El-Saied, H.;Deffallah, E.M. 2014b. Optimising the process for production of high performance bagasse-based composites from rice bran-UF adhesive system. Pigment and Resin Technology 43 (4): 212-218.

Basta, A.H.; El-Saied, H.; .Deffallah E.M. 2016. Effects of denaturisation of rice bran and route of synthesis of RB-modified UF adhesive system on eco-performance of agro-based composites. Pigment and Resin Technology 54 (3): 172-183.

Ciannamea, E.; Stefani, P.M.; Ruseckaite, R.A. 2010. Medium Density fiberboard from rice husks and soybean protein concentrate-based adhesive. Bioresource Technology 101: 818-25.

Coats, A.W.; Redfern; J.P. 1994. Kinetic parameters from thermogravimetric data. Nature 201: $68-72$.

Copur, Y.; Gular, C.; Tascioglu, C.; Tozluoglu,A. 2008. Incorporation of hazelnut shell and husk in MDF production. Bioresource Technology 99: 7402-06.

El-Nashar, D.E.; Abd-El-Messieh, S.L.; Basta, A.H. 2004. Newsprint paper waste as a fiber reinforcement in rubber composites. Journal of Applied Polymer Science 91 (5): 3410-3420.

El-Saied, H.; Fadl, M.H.; Basta, A.H. 1996. Properties of bagasse hardboard made by in-situ formation of phenol-lignin formaldehyde resin. Polymers \& Polymer Composites 4 (7): 519-522.

El-Saied, H.; Basta, A.H., Hassanen, M.E.; Korte, H.; Helal, A. 2012. Behaviour of RiceByproducts and Optimizing the Conditions for Production of High Performance Natural Fiber Polymer Composites. Journal of Polymers and the Environment 20 (3): 838-847.

European Standard. EN. 1992. The for determination of free formaldehyde in wood-based panels Perforator method EN 120. 1992.

Faraji, H.R. 1998. Investigation on properties of medium density fiberboard (MDF) produced from bagasse. M.Sc. Thesis. Tarbiat Modares University, Faculty of Natural Resources and Marine Science.

Fathy, N.|A.; Lotfy, V.F.; Basta, A.H. 2017. Comparative study on the performance of carbon nanotubes prepared from agro-and xerogels as carbon supports. Journal of Analytical and Applied Pyrolysis (128):114-120.

Halvarsson, S.; Edlund, H.; Norgren, M. 2008. Properties of MDF based on wheat straw and melamine modified urea- formaldehyde (UMF) resin. Industrial Crops and Products 28: 37-46.

Hossein, Y. 2009. Canola straw as a bio-waste resource for medium density fiberboard manufacture. Waste Management 29 (10): 2644-2648. 
Istek, A.; Aydemir, D.; Eroglu, H. 2012. Surface properties of MDF coated with calcite/clay and effects of fire retardants on surface properties. Maderas-Cienc Tecnol 14(2): 135-144.

Jayme, G.; Sarten, P. 1940. Über die quantitative bestimmung von pentosen mittels bromwasserstoff-sauer. Naturewise 28 (52): 822-23.

Lee, S.; Shupe, T.F.; Hse, C.Y. 2006. Mechanical and physical properties of agro-based fiberboard. Holz-als-Roh-und-Werkstoff 64: 74-79.

Li, X.; Cai, Z.; Winandy, J.E.; Basta, A.H. 2011. Effect of Oxalic Acid and Steam Pretreatment on the Primary Properties of UF-bonded Rice Straw Particleboards. Industrial Crops and Products 33: 665- 669 .

Mahmoudi, H.; Hosseininia, G.; Azadi, H.; Fatemi, M. 2008. Enhancing date Palm processing marketing and pest control through organic culture. J Organic Systems 3 (2): 29-39.

Roffael, E.; Behn, C.; Krug, D.; Weber, A.; Hartwig-Gerth, C.; Gräfe, G. 2011. UF- und PMDI-Doppelbeleimung bei Faserplatten. Holz-Zentralblatt 137: 1216-1217.

Sivakumar, V.; Asaithambi, M.; Sivakumar, P. 2012. Physico-chemical and adsorption studies of activated carbon from agricultural wastes. Advances in Applied Science Research 3 (1): 219-226.

Technical Association of the Pulp and Paper Industry. TAPPI. 1978. Determination of cellulose TAPPI T429. 1978. Atlanta, GA.

Technical Association of the Pulp and Paper Industry. TAPPI. 1998. Test Method T222. Determination of acid insoluble lignin TAPPI T222. 1998. Atlanta, GA.

Thakur, V.K.; Singha, A.S.; Thakur, M.K. 2012a. Graft copolymerization of methyl acrylate onto cellulosic biofibers: Synthesis, characterization and applications. Journal of Polymers and the Environmen 20 (1): 164-174.

Thakur, V.K.; Singha, A.S.; Thakur, M.K. 2012b. Surface modification of natural polymers to impart low water absorbency. International Journal of Polymer Analysis and Characterization 17: 133-143.

Thakur, V.K.; Singha, A.S.; Thakur, M.K. 2012c. In-air Graft copolymerization of Ethylacrylate onto Natural Cellulosic Polymers. International Journal of Polymer Analysis and Characterization 17: 48-60.

Thakur, V.K.; Thakur, M.K.; Gupta, R.K. 2014. Graft copolymers of natural cellulose for green composites. Carbohydrate Polymers 104: 87-93.

Taghiyari, H. R.; Nouri. P. 2015. Effect of nano-wollastonite on physical and mechanical properties of medium density fiberboard. Maderas-Cienc Tecnol 17(4): 833 - 842.

Taghiyari, H.R.; Nouri. P. 2016. Effect of wollastonite on physical and mechanical properties of medium density fiberboard (MDF) made from wood fibers and camel-thorn. Maderas-Cienc Tecnol 18(1): $157-166$.

Wise, L.F.; Murphy, M.; D'assiece, A.A. 1946. A chlorite holocellulose, its fractionation and bearing on summative wood analysis and studies on the hemicelluloses. Paper Trade Journal 122 (2): 35.-43.

Ye, X.P.; Julson, J; Kuo, M.; Womac, A.; Myers, D. 2007. Properties of medium density fiberboard made from renewable biomass. Bioresource Technology 98: 1077-1084. 
Younesi-Kordkheili, H.; Pizzi, A. 2018. Properties of plywood panels bonded with ionic liquidmodified lignin-phenol-formaldehyde resin. The Journal of Adhesion 94(2): 143-154. 